\title{
Pengaruh Penilaian Prestasi Kerja dan Kompensasi Terhadap Motivasi Kerja Serta Dampaknya Terhadap Kinerja Karyawan pada PT. Bank Central Asia Tbk Kantor Cabang Utama Jambi
}

\author{
Dewi Marlinda, Fakhrul Rozi Yamali, M. Zahari MS \\ Program Magister Manajemen FE Unbari \\ Correspondence email: fakhrul_65@yahoo.co.id
}

\begin{abstract}
Abstrak. Tujuan penelitian ini adalah untuk memperoleh gambaran mengenai penilaian prestasi kerja, kompensasi, motivasi kerja dan kinerja karyawan pada PT. BCA Tbk KCU Jambi; dan untuk mengetahui pengaruh penilaian prestasi kerja dan kompensasi secara langsung dan tidak langsung terhadap motivasi kerja dan kinerja karyawan; serta untuk mengetahui pengaruh motivasi terhadap kinerja. Populasi pada penelitian ini adalah karyawan pada PT. BCA Tbk KCU Jambi dengan jumlah 125 orang karyawan. Ukuran atau jumlah sampel dalam penelitian ini ditentukan berdasarkan teori yang dikembangkan oleh Slovin dengan nilai e $=10 \%$, sehingga diperoleh sampel sebanyak 56. Teknik analisis menggunakan path analisis untuk melihat pengaruh langsung dan tidak langsung, serta diteruskan dengan menguji R Square dan pengujian hipotesis secara parsial dan simultan dengan uji t dan uji F. Dari pengujian path analisis yang dilakukan, hasil penelitian menunjukan bahwasanya penilaian prestasi kerja dan kompensasi mempunyai pengaruh terhadap motivasi dan kinerja karyawan, baik secara langsung maupun tidak langsung. Dimana berdasarkan hasil uji t (parsial) dan uji F (Simultan) menunjukan bahwasanya penilaian prestasi kerja dan kompensasi memiliki pengaruh yang signifikan dan positif terhadap motivasi dan kinerja, begitu pula motivasi juga memiliki pengaruh yang signifikan dan positif terhadap kinerja. Hal ini menjelaskan bahwasanya jika penilaian prestasi kerjan dan kompensasi dapat dilaksanakan dengan baik, maka akan memberikan pengaruh positif dalam meningkatkan motivasi kerja yang berimplikasi terhadap peningkatan kinerja karyawan pada PT. BCA Tbk KCU Jambi. Berdasarkan beberapa kesimpulan yang diperoleh, adapun saran yang dapat penulis berikan dalam penelitian ini diantaranya yaitu Dimasa mendatang diharapkan pimpinan PT. Bank Central Asia. Tbk Kantor Cabang Utama Jambi dapat melaksanakan penilaian prestasi kerja dilaksanakan secara objektif. Selain itu penelitian ini perlu ditindak lanjuti lagi untuk melihat faktor apa yang dapat memengaruhi kinerja karyawan secara komprehensif, guna menjawab faktor lain (epsilon) yang mempengaruhi kinerja karyawan.
\end{abstract}

Kata Kunci: Penilaian Prestasi Kerja, Kompensasi, Motivasi dan Kinerja.

\begin{abstract}
The purpose of this research is to obtain an overview of the assessment of work performance, compensation, work motivation and employee performance at PT. BCA Tbk KCU Jambi; and to know the effect of work performance assessment and compensation directly and indirectly on employee motivation and performance; and to know the influence of motivation on performance. The population in this study was employees at PT. Bca. Tbk KCU Jambi with a total of 125 employees. The size or number of samples in this study was determined based on the theory developed by Slovin with a value of e $=10 \%$, so that 56 samples were obtained. Analysis techniques use path analysis to see direct and indirect influence, and continued by testing $R$ Square and hypothesis testing partially and simultaneously with t test and $F$ test. Where based on the results of t test (partial) and test $F$ (Simultaneous) shows that the assessment of work performance and compensation has a significant and positive influence on motivation and performance, as well as motivation also has a significant and positive influence on performance. This explains that if the assessment of work performance and compensation can be carried out properly, it will have a positive influence in improving the motivation of work that has implications for improving employee performance at PT. BCA Tbk KCU Jambi. Based on some of the conclusions obtained, the suggestions that can be given in this study include the future expected leadership of PT. Bank Central Asia. Tbk Jambi Main Branch Office can carry out performance assessments carried out objectively. In addition, this research needs to be followed up again to see what factors can affect employee performance comprehensively, in order to answer other factors (epsilon) that affect employee performance.
\end{abstract}

Keywords: Work Performance Assessment, Compensation, Motivation and Performance.

\section{Pendahuluan}

Eksistensi setiap perusahaan akan dapat dipertahankan apabila perusahaan tersebut mampu mengoptimalkan segenap sumber daya yang dimilikinya seoptimal mungkin. Keberadaan SDM dalam sebuah organisasi sangat penting karena merekalah yang memprakarsai terbentuknya organisasi, berperan untuk membuat keputusan pada semua fungsi, dan menentukkan keberlangsungan hidup organisasi tersebut (Panggabean, 2010). Schuler dan Jackson (2010) menyatakan bahwa mengelola SDM bukan lagi merupakan suatu pilihan melainkan sudah menjadi keharusan. Karena untuk bisa sukses dalam pasar yang kompetitif, mereka harus memiliki orang-orang terbaik di seluruh bagian perusahaan mereka. Tak terkecuali pula dengan PT. Bank Central Asia (BCA) Tbk Kantor Cabang Utama (KCU) Jambi. Sebagai salah satu bank swasta terbesar di Indonesia yang melayani beragam segmen nasabah, baik 
nasabah individu maupun nasabah bisnis, tentu harus mampu mengelola SDM yang ada dengan baik, agar SDM yang ada dapat berkualitas dan terampil dalam melaksanakan tugas-tugasnya.

Melihat dari fenomena tersebut, maka sudah selayaknya bagi manajemen perusahaan untuk mengelola SDMnya dengan melakukan evaluasi pekerjaan melalui penilaian secara sistematik yang berhubungan dengan kinerja prestasinya. Penilaian prestasi kerja adalah sebuah proses formal untuk melakukan peninjauan ulang dan evaluasi prestasi kerja seseorang secara periodik (Panggabean, 2010). Penilaian prestasi kerja pada dasarnya bertujuan untuk memperbaiki dan meningkatkan prestasi kerja karyawan serta memperoleh informasi yang berguna dalam pengambilan keputusan yang berkaitan dengan kegiatan manajemen SDM yang lain (Thomas dan Brez JR dalam Hasibuan, 2009). Kegiatan-kegiatan tersebut seperti perencanaan SDM, penarikan dan seleksi, pengembangan SDM, perencanaan dan pengembangan karier, program-program kompensasi, promosi, demosi, pensiun, dan pemecatan (Panggabean, 2010).

Penilaian prestasi kerja haruslah dilakukan secara adil, objektif, transparan, konsisten dan sensitive, karena penilaian ini kedepannya akan memiliki efek positif terhadap motivasi individual. Hal ini diungkapkan Chandra (2010) bahwa apabila penilaian prestasi kerja dilaksanakan dengan metode yang tepat sehingga hasilnya objektif, yaitu sesuai dengan prestasi kerja karyawan, dan imbalan yang diberikan sesuai dengan keobjektifan penilaian tersebut, maka motivasi karyawan akan meningkat. Sejalan dengan Chandra, Hasibuan (2009) mengatakan bahwa salah satu kegunaan dari penilaian prestasi kerja adalah untuk meningkatkan motivasi kerja karyawan sehingga dicapai tujuan untuk mendapatkan kinerja yang baik. Di dalam suatu perusahaan, setiap karyawan mempunyai kepentingan dan tujuan yang berbeda-beda ketika bergabung pada perusahaan. Sebagian karyawan menganggap uang adalah satu-satunya tujuan mereka bekerja. Sebagian lain, merasa ketika bekerja mereka lebih dihargai oleh masyarakat sekitar. Sementara lainnya beralasan bekerja untuk aktualisasi diri, sosial, mencari jodoh, dan lain-lain. Maka dari itu, dengan berbagai macam alasan-alasan yang melatarbelakangi karyawan untuk bekerja, dibutuhkan sistem kompensasi. Kompensasi adalah keseluruhan balas jasa yang diterima oleh karyawan sebagai akibat dari pelaksanaan pekerjaan di organisasi dalam bentuk uang atau lainnya (Hariandja, 2007).

Kompensasi memegang peranan penting dalam meningkatkan kinerja karyawan karena salah satu alasan utama seseorang bekerja adalah untuk memenuhi kebutuhan hidupnya dari imbalan yang mereka terima dari bekerja. Menurut Hasibuan (2009) kompensasi adalah semua pendapatan yang berbentuk uang, barang langsung, atau tidak langsung yang diterima karyawan sebagai imbalan atas jasa yang diberikan kepada perusahaan. Salah satu tujuan pemberian kompensasi meningkatkan prestasi kerja karyawan. Hal tersebut selanjutnya akan mendorong kinerja sesuai yang diinginkan organisasi (Sedarmayanti 2013). Berdasarkan dari penjelasan tersebut, maka sudah semestinyalah manajemen perusahaan memperbaiki sistem peniliaian prestasi kerja karyawan. Karena penilaian yang tepat sasaran dapat digunakan untuk menentukkan tindakan yang tepat terhadap para karyawan. Handoko (2010) mengungkapkan salah satu tindakan yang dapat diambil system penilaian prestasi kerja karyawan adalah menentukkan pemberian kompensasi dan penempatan seperti promosi jabatan kepada karyawan yang berprestasi atau karyawan dengan kinerja yang meningkat dari sebelumnya.

Selain itu penilaian prestasi kerja yang adil dan objektif juga dapat mendorong semangat kerja karyawan agar mau bekerja keras dan memberikan semua kemampuan serta ketrampilan demi tercapainya tujuan perusahaan. Motivasi kerja karyawan penting karena dengan motivasi kerja karyawan, diharapkan setiap individu karyawan mau bekerja keras dan antusias untuk mencapai kinerja yang tinggi (Martinus, E., dan Budiyanto., 2016). Tujuan dari peneltian ini adalah memperoleh gambaran penilaian prestasi kerja, kompensasi, motivasi kerja dan kinerja karyawan pada PT. BCA Tbk KCU Jambi, serta mengetahui pengaruh penilaian prestasi kerja dan kompensasi terhadap motivasi kerja dan kinerja karyawan baik secara langsung maupun tidak langsung."

\section{Landasan Teori \\ Karakteristik Pekerjaan}

Penilaian prestasi kerja adalah evaluasi yang sistematis terhadap pekerjaan yang telah dilakukan oleh karyawan dan ditunjukan untuk pengembangan (Sikula dalam Hasibuan, 2009). Mangkunegara (2011) menjelaskan penilaian prestasi pegawai yang dilakukan pemimpin perusahaan secara sistematik berdasarkan pekerjaan yang ditugaskan kepadanya. Selain itu Rivai (2009) menjelaskan penilaian prestasi adalah merupakan hasil kerja karyawan dalam lingkup tanggung jawabnya. Lebih lanjut Sutrisno (2014) menjelaskan suatu proses penilaian prestasi kerja yang dilakukan pemimpin perusahaan secara sistematik berdasarkan pekerjaan yang ditugaskan kepadanya. Penilaian prestasi kerja mempunyai dasar yang sangat penting bagi perusahaan atau instansi pemerintahan sebagai alat untuk mengambil keputusan bagi pegawai. Penilaian prestasi mempunyai banyak kegunaan di dalam suatu organisasi. Menurut Handoko (2010) terdapat delapan manfaat yang dapat dipetik dari penilaian prestasi kerja tersebut di halaman berikutnya: 1) Perbaikan Prestasi kerja; 2) Penyesuaian-penyesuaian kompensasi; 3) Keputusan-keputusan penempatan; 4) Kebutuhan-kebutuhan latihan dan pengembangan; 5) Perencanaan dan pengembangan karir; 6) 
Penyimpangan-penyimpangan proses staffing; 7) Kesempatan kerja yang adil; dan 8) Tantangan-tantangan eksternal. Penilaian prestasi kerja karyawan dalam suatu perusahaan bermacam-macam tergantung penetapan perusahaan itu sendiri, tetapi pada umumnya dimensi penilaian prestasi kerja menurut Soeprihanto (2009) adalah sebagai berikut: 1) Adil; 2) Objektif; 3) Transparan; 4) Konsisten; dan 5) Sensitif.

\section{Kompensasi}

Kompensasi merupakan sesuatu yang diterima karyawan sebagai pengganti kontribusi jasa mereka pada perusahaan. Pemberian kompensasi merupakan salah satu pelaksanaan fungsi MSDM yang berhubungan dengan semua jenis penghargaan individual sebagai pertukaran dalam melakukan tugas keorganisasian (Rivai dan Sagala, 2011). Singodimedjo dalam Sutrisno (2014) mengemukakan kompensasi adalah semua balas jasa yang diterima seorang karyawan dari perusahaannya sebagai akibat dari jasa/tenaga yang telah diberikannya pada perusahaan tersebut. Sedangkan menurut Simamora (2009) Kompensasi adalah semua bentuk kembalian financial, jasa-jasa terwujud dan tunjangan yang diperoleh karyawan sebagai bagian dari hubungan kekaryawanan. Menurut Notoadmodjo dalam Sutrisno (2014) ada beberapa tujuan dari kompensasi yang perlu diperhatikan, yaitu: 1) Menghargai prestasi kerja; 2) Menjamin keadilan; 3) Mempertahankan karyawan; 4) Memperoleh karyawan yang bermutu; 5) Pengendalian biaya; dan 6) Memenuhi peraturan-peraturan. Menurut Rivai dan Sagala (2011) berdasarkan jenisnya kompensasi dikelompokan kedalam dua kelompok yaitu kompensasi finasial dan kompensai non finansial. Selanjtunya kompensasi finansial terdiri dari kompensasi langsung dan kompensasi tidak langsung. Kompensasi langsung terdiri dari pembayaran langsung kepada karyawan berupa upah, gaji, bonus atau komisi. Sedangkan kompensasi tidak langsung terdiri dari semua pembayaran yang tidak tercakup dalam kompensasi finansial langsung yang meliputi liburan, berbagai macam asuransi, jasa seperti perawatan anak atau kepedulian keagamaan dan sebagainya. Sedangkan untuk kompensasi non finansial yaitu dapat berupa pujian, menghargai diri sendiri dan pengakuan dapat memengaruhi motivasi kerja karyawan, produktifitas dan kepuasan.

\section{Motivasi Kerja}

Motivasi kerja merupakan kombinasi kekuatan psikologis yang kompleks dalam diri masing-masing orang (Wibowo, 2014). Menurut McClelland dalam Mangkunegara (2011) Motivasi merupakan Kondisi jiwa yang mendorong seseorang dalam mencapai prestasinya secara maksimal. Sedangkan menurut Rivai (2009) motivasi merupakan serangkaian sikap dan nilai-nilai yang mempengaruhi individu untuk mencapai hal yang spesifik sesuai dengan tujuan individu. Hasibuan (2009) juga memberikan definisi motivasi kerja adalah pemberian daya penggerak yang menciptakan kegairahan kerja seseorang agar mereka mau bekerja sama, bekerja efektif, dan terintegrasi dengan segala daya upayanya untuk mencapai kepuasan. Robbin dan Judge (2015) mendefinisikan motivasi sebagai proses yang menjelaskan mengenai kekuatan, arah, dan ketekunan seseorang dalam upaya untuk mencapai tujuan. Oleh karena motivasi secara umum adalah berkaitan dengan upaya menuju setiap tujuan, kita kan mempersempit fokus menjadi tujuan organisasi terhadap perilaku terkait pekerjaan. David McClelland dalam Mangkunegara (2011), mengemukakan enam karakteristik orang yang mempunyai motif berprestasi tinggi, yaitu: a) Memiliki tingkat tanggung jawab pribadi yang tinggi; 2) Berani mengambil dan memikul resiko; c) Memiliki tujuan yang realistic; d) Memiliki rencana kerja yang menyeluruh dan berjuang untuk merealisasi tujuan; e) Memanfaatkan umpan balik yang konkrit dalam semua kegiatan yang dilakukan; dan f) Mencari kesempatan untuk merealisasikan rencana yang telah diprogramkan. McClelland dalam Mangkunegara (2011) mengemukakan bahwa produktivitas seseorang sangat ditentukan oleh "virus mental" yang ada pada dirinya.Virus mental adalah kondisi jiwa yang mendorong seseorang yang mampu mencapai prestasinya secara maksimal. Virus mental yang dimaksud terdiri dari 3 dorongan kemampuan, yaitu: 1) Need of achievement (kebutuhan untuk berprestasi); 2) Need of affiliation (kebutuhan untuk memperluas pergaulan); dan 3) Need of power (kebutuhan untuk menguasai sesuatu).

\section{Kinerja}

Istilah kinerja berasal dari kata job performance atau actual performance (prestasi kerja atau prestasi sesungguhnya yang dicapai seseorang) yaitu hasil kerja secara kualitas dan kuantitas yang dicapai oleh seorang pegawai dalam melaksanakan tugasnya sesuai dengan tanggung jawab yang diberikan kepadanya (Mangkunegara, 2011). Pengertian tersebut memberikan pemahaman bahwa kinerja merupakan suatu perbuatan atau perilaku seseorang dalam pelaksanaan tugasnya, yang dapat diamati dan dinilai oleh orang lain. Kinerja merupakan suatu fungsi dari motivasi dan kemampuan untuk menyelesaikan tugas atau pekerjaan seseorang sepatutnya memiliki derajat kesediaan dan tingkat kemampuan tertentu. Kesediaan dan keterampilan seseorang tidaklah cukup efektif untuk mengerjakan sesuatu tanpa pemahaman yang jelas tentang apa yang akan dikerjakan dan bagaimana mengerjakannya. Kinerja merupakan perilaku nyata yang ditampilkan setiap orang sebagai prestasi kerja yang dihasilkan oleh karyawan sesuai dengan perannya dalam organisasi. Kinerja karyawan merupakan suatu hal yang sangat penting dalam upaya 
organisasi untuk mencapai tujuan (Rivai dan Sagala, 2011). Mathis (2009) mengatakan kinerja merupakan banyaknya upaya yang dikeluarkan individu dalam mencurahkan tenaga sejumlah tertentu pada pekerjaan. Sedangkan menurut Simamora (2009) kinerja merupakan tingkat terhadap mana para pegawai dalam melaksanakan tugasnya sesuai dengan tanggung jawab yang diberikan kepadanya. Sedangkan menurut menurut Sutrisno (2014) mendefinisikan kinerja sebagai prestasi yang diperoleh seseorang dalam melakukan tugas. Menurut Sedarmayanti (2013), faktorfaktor yang mempengaruhi kinerja antara lain :1) Sikap dan mental (motivasi kerja, disiplin kerja, dan etika kerja), 2) Pendidikan, 3) Keterampilan, 4) Manajemen kepemimpinan, 5) Tingkat penghasilan, 6) Gaji dan kesehatan, 7) Jaminan sosial, 8) Iklim kerja, 9) Sarana dan prasarana, 10) Teknologi, dan 11) Kesempatan berprestasi. Sedangkan menurut Mathis (2009) mengemukakan bahwa aspek-aspek yang dinilai dalam kinerja adalah sebagai berikut: 1) Kuantitas kerja; 2) Kualitas kerja; 3) Pemanfaatan waktu; 4) Kerjasama; 5) Kehadiran.

\section{Hipotesis}

$\mathrm{H}_{1}$ : Diduga penilaian prestasi kerja, kompensasi, motivasi kerja dan kinerja karyawan pada PT. BCA Tbk Kantor Cabang Utama (KCU) Jambi dalam kondisi baik.

$\mathrm{H}_{2}$ : Penilaian prestasi kerja dan kompensasi secara secara langsung dan tidak langsung terhadap motivasi kerja karyawan pada PT. BCA Tbk. KCU Jambi.

$\mathrm{H}_{3}$ : Penilaian prestasi kerja dan kompensasi secara secara langsung dan tidak langsung terhadap kinerja karyawan pada PT. BCA Tbk. KCU Jambi.

$\mathrm{H}_{4}$ : Motivasi kerja secara parsial berpengaruh signifikan terhadap kinerja karyawan pada PT. BCA Tbk. KCU Jambi.

$\mathrm{H}_{5}$ : Penilaian prestasi kerja dan kompensasi melalui motivasi berpengaruh signifikan terhadap kinerja karyawan pada

PT. BCA Tbk. KCU Jambi.

\section{Metode}

Metode penelitian yang digunakan adalah metode penelitian survey dengan membuat angket kepada responden (karyawan) yang akan menjawab pernyataan-pernyataan tentang pengaruh penilaian prestasi kerja, kompensasi, motivasi kerja dan kinerja karyawan pada PT. BCA Tbk Kantor Cabang Utama (KCU) Jambi. Tingkat eksplanasi (level of explanation) penelitian ini adalah penelitian deskriptif dan verifikatif. Adapun alat analisis yang digunakan dalan penelitian ini adalah alat analisis jalur (path analysis). Populasi pada penelitian ini adalah karyawan pada PT. BCA. Tbk KCU Jambi yang berjumlah 125 orang karyawan. Ukuran atau jumlah sampel dalam penelitian ini ditentukan berdasarkan teori yang dikembangkan oleh Slovin dengan nilai e $=10 \%$. Sehingga diperoleh sampel sebanyak 56.

\section{Analisis Jalur (Path Analysis)}

Path Analysis adalah teknik statistik yang digunakan untuk menguji hubungan struktural atau kausal antara dua atau lebih variabel, dimana dalam hal ini variabel yang dimaksud adalah karakteristik pekerjaan, komitmen pegawai, dan kinerja pegawai dan satu variabel intervening yaitu motivasi. Variable intervening merupakan variabel antara atau mediasi yang fungsinya memediasi hubungan antara variabel independen kepada variabel dependen. Untuk menguji variabel intervening digunakan metode analisis jalur, sebagai perluasan dari analisis regresi linier berganda. Diagram jalur dalam penelitian terdiri dari tiga sub structural, dimana $\mathrm{X}_{1}$ dan $\mathrm{X}_{2}$ adalah variabel eksogen (exogenous) yaitu variabel yang tidak ada penyebab eksplisit nya, variabel ini berfungsi sebagai variabel bebas/penyebab terhadap variabel urutan sesudah nya yaitu $\mathrm{Y}$ serta $\mathrm{Z}$ sebagai variabel endogen (endogenous) dimana $\mathrm{Y}$ merupakan variabel perantara dan $\mathrm{Z}$ adalah variabel tergantung. Setelah data dialysis melalui analisis jalur, kemudian dilanjutkan melakukan uji hipotesis melalui uji t secara parsial, dan uji uji F secara simultan.

\section{Hasil}

Tabel 1

Output SPSS Tiga Sub Struktur.

\begin{tabular}{|c|c|c|c|c|c|c|}
\hline \multirow{2}{*}{ Model } & \multicolumn{2}{|c|}{ Unstandardized Coefficients } & \multirow{2}{*}{ Beta } & \multirow{2}{*}{$\mathbf{t}$} & \multirow{2}{*}{$\mathbf{F}$} & \multirow{2}{*}{ Sig. } \\
\hline & B & Std.Error & & & & \\
\hline $\mathrm{X} 1-\mathrm{Y}$ & 0,298 & 0,064 & 0,385 & 4,664 & - & 0,000 \\
\hline $\mathrm{X} 2-\mathrm{Y}$ & 0,560 & 0,078 & 0,596 & 7,211 & - & 0,000 \\
\hline $\mathrm{X} 1, \mathrm{X} 2-\mathrm{Y}$ & - & - & - & - & 67,352 & 0,000 \\
\hline $\mathrm{X} 1-\mathrm{Z}$ & 0,304 & 0,075 & 0,474 & 4,084 & - & 0,000 \\
\hline $\mathrm{X} 2-\mathrm{Z}$ & 0,230 & 0,091 & 0,295 & 2,538 & - & 0,014 \\
\hline $\mathrm{X} 1, \mathrm{X} 2-\mathrm{Z}$ & - & - & - & - & 21,008 & 0,000 \\
\hline $\mathrm{X} 3-\mathrm{Z}$ & 0,488 & 0,091 & 0,589 & 5,352 & - & 0,000 \\
\hline
\end{tabular}

Sumber: Data olahan 


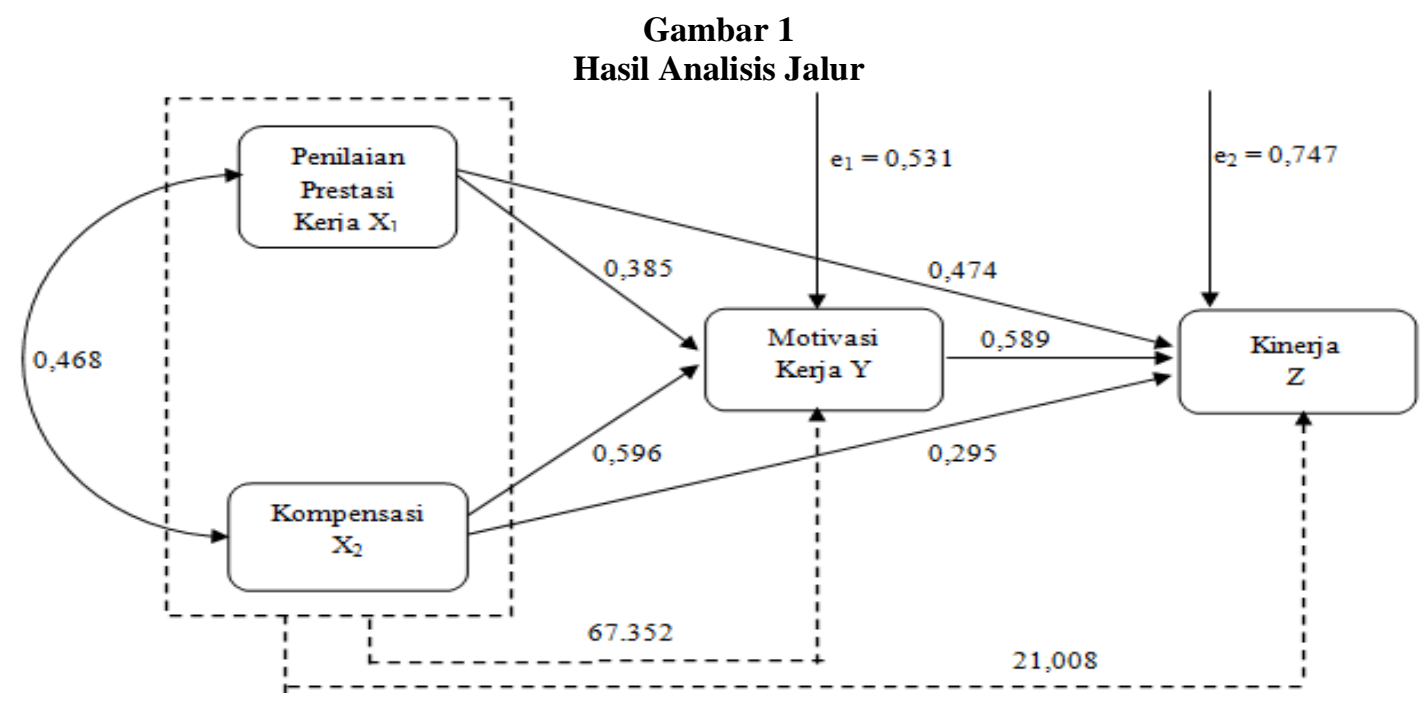

Tabel 3.

Rekapitulasi Pengaruh Langsung dan Tidak Langsung Penilaian Prestasi Kerja dan Kompensasi Terhadap Motivasi.

\begin{tabular}{|c|c|c|c|c|c|}
\hline \multirow{2}{*}{ Variabel } & \multirow{2}{*}{ Langsung } & \multicolumn{2}{|c|}{ Tidak Langsung } & \multirow{2}{*}{ Sub Total } & \multirow{2}{*}{ Total } \\
\hline & & $\mathbf{X}_{1}$ & $\mathbf{X}_{2}$ & & \\
\hline Penilaian Prestasi Kerja $\left(\mathrm{X}_{1}\right)$ & $14,82 \%$ & & $10,74 \%$ & $10,74 \%$ & $25,56 \%$ \\
\hline Kompensasi $\left(\mathrm{X}_{2}\right)$ & $35,52 \%$ & $10,74 \%$ & & $10,74 \%$ & $46,26 \%$ \\
\hline \multicolumn{5}{|l|}{ Pengaruh $\mathrm{X}_{1}, \mathrm{X}_{2}$} & $71,82 \%$ \\
\hline \multicolumn{5}{|l|}{ Pengaruh variabel lain } & $28,18 \%$ \\
\hline
\end{tabular}

Sumber: Data olahan

Hasil analisis jalur yang dilakukan diperoleh pengaruh langsung penilaian prestasi kerja terhadap motivasi kerja sebesar 14,82\%, kompensasi terhadap motivasi kerja sebesar 35,52\% dan total pengaruh penilaian prestasi kerja dan kompensasi terhadap motivasi kerja secara langsung maupun tidak langsung sebesar 71,8.

Tabel 4

Koefisien Determinasi

\begin{tabular}{|c|c|c|c|c|}
\hline Model & $\mathrm{R}$ & R Square & Adjusted R Square & Std. Error of the Estimate \\
\hline 1 &, $847^{\mathrm{a}}$ &, 718 &, 707 &, 180330127315683 \\
\hline
\end{tabular}

Sumber: Data olahan

Nilai R sebesar 0,847 menunjukan korelasi ganda (penilaian prestasi kerja dan kompensasi) dengan motivasi. Dengan mempertimbangkan variasi Nilai R Square sebesar 0,718 yang menunjukan besarnya peran atau kontribusi variabel penilaian prestasi kerja dan kompensasi mampu menjelaskan variabel motivasi sebesar $71,8 \%$ dan sisanya $28,2 \%$ dipengaruhi oleh variabel lain yang tidak termasuk dalam model ini.

Tabel 5.

Rekapitulasi Pengaruh Langsung dan Tidak Langsung Penilaian Prestasi Kerja dan Kompensasi terhadap Kinerja

\begin{tabular}{|l|r|r|r|r|r|}
\hline \multicolumn{1}{|c|}{ Variabel } & \multirow{2}{*}{ Langsung } & \multicolumn{2}{|c|}{ Tidak Langsung } & \multirow{2}{*}{ Sub Total } & \multirow{2}{*}{ Total } \\
\cline { 4 - 5 } & & $\mathbf{X}_{\mathbf{1}}$ & $\mathbf{X}_{\mathbf{2}}$ & \\
\hline Penilaian Prestasi Kerja $\left(\mathrm{X}_{1}\right)$ & $22,47 \%$ & & $6,54 \%$ & $6,54 \%$ & $29,01 \%$ \\
\hline Kompensasi $\left(\mathrm{X}_{2}\right)$ & $8,70 \%$ & $6,54 \%$ & & $6,54 \%$ & $15,24 \%$ \\
\hline Pengaruh $\mathrm{X}_{1}, \mathrm{X}_{2}$ & & & $44,25 \%$ \\
\hline Pengaruh variabel lain & & & \\
\hline
\end{tabular}

Sumber: Data olahan

Hasil analisis jalur yang dilakukan diperoleh pengaruh langsung penilaian prestasi kerja terhadap kinerja sebesar 22,47\%, kompensasi terhadap Kinerja sebesar 8,70\% dan total pengaruh penilaian prestasi kerja dan kompensasi terhadap kinerja secara langsung maupun tidak langsung sebesar 44,25. 
Dewi Marlinda, Fakhrul Rozi Yamali dan M. Zahari MS, Pengaruh Penilaian Prestasi Kerja dan Kompensasi Terhadap Motivasi Kerja Serta Dampaknya Terhadap Kinerja Karyawan pada PT Bank Central Asia Tbk Kantor Cabang Utama Jambi

\begin{tabular}{|c|c|c|c|c|}
\hline \multicolumn{5}{|c|}{ Koefisien Determinasi } \\
\hline Model & $\mathrm{R}$ & R Square & Adjusted R Square & Std. Error of the Estimate \\
\hline 1 &, $665^{\mathrm{a}}$ & ,442 & ,421 & ,210134497889309 \\
\hline
\end{tabular}

Sumber: Data olahan

Nilai R sebesar 0,665 menunjukan korelasi ganda (penilaian prestasi kerja dan kompensasi) dengan kinerja. Dengan mempertimbangkan variasi nilai $\mathrm{R}$ Square sebesar 0,442 yang menunjukan besarnya peran atau kontribusi variabel penilaian prestasi kerja dan kompensasi mampu menjelaskan variabel kinerja sebesar $44,2 \%$ dan sisanya 55,8\% dipengaruhi oleh variabel lain yang tidak termasuk dalam model ini. Kemudian dari hasil analisis jalur pengaruh langsung motivasi terhadap kinerja sebesar 34,69\%, ini menunjukan bahwa motivasi secara langsung berpengaruh terhadap kinerja karyawan pada PT. BCA. Tbk KCU Jambi. Hal ini menjelaskan bahwasanya apabila karyawan memiliki motivasi kerja yang tinggi dalam melaksanakan tugas pokok dan fungsinya, maka karyawan tersebut akan mampu memberikan kontribusi kerja yang baik pula dalam upaya mencapai tujuan perusahaan. Nilai tersebut menjelaskan nilai koefisien determinasi $\mathrm{R}^{2}$ Square seperti yang tampak pada tabel berikut.

Tabel 7.

Koefisien Determinasi

\begin{tabular}{|c|c|c|c|c|}
\hline Model & $\mathrm{R}$ & R Square & Adjusted R Square & Std. Error of the Estimate \\
\hline 1 &, $589^{\mathrm{a}}$ & ,347 & $\mathrm{J}$ & ,225309429463873 \\
\hline
\end{tabular}

Sumber: Data olahan

Nilai R Square sebesar 0,347 menunjukan besarnya peran atau kontribusi variabel motivasi mampu menjelaskan variabel kinerja sebesar $34,7 \%$ dan sisanya sebesar 65,3\% dipengaruhi oleh variabel lain yang tidak termasuk dalam model ini.

\section{Penilaian Prestasi Kerja dan Kompensasi Secara Langsung dan Tidak Langsung Berpengaruh Terhadap Motivasi Kerja.}

Penilaian Prestasi Kerja Berpengaruh Terhadap Motivasi Kerja

Hasil output SPSS sperti yang tampak pada Tabel 2 yang dilakukan diperoleh nilai t hitung variabel $\mathrm{X}_{1}$ lebih besar dari nilai t tabel $(4,664>2,0048)$, dengan tingkat signifikansi sebesar 0,000 , dikarenakan angka taraf signifikansi lebih $<0,05(0,000<0.05)$ maka dapat disimpulkan bahwa penilaian prestasi kerja berpengaruh terhadap motivasi kerja karyawan. Berdasarkan dari penjelasan tersebut oleh karena itu $\mathrm{H}_{0}$ ditolak dan $\mathrm{H}_{1}$ diterima, artinya penilaian prestasi kerja secara langsung dan tidak langsung berpengaruh terhadap motivasi kerja karyawan. Hasil penelitian ini menunjukan hasil yang sama dengan penelitian yang dilakukan oleh Pribadi, J.A., dan Harjianti, D (2014) dimana hasil penelitiannya menunjukan bahwa penilaian prestasi kerja dapat berpengaruh terhadap motivasi kerja. Penilaian prestasi kerja karyawan erat kaitannya dengan motivasi kerja karyawan. Oleh karena itu penilaian prestasi keraj harus dilaksanakan seiring dengan situasi dan kondisi yang dihadapi oleh perusahaan untuk mendukung terciptanya motivasi kerja yang tinggi pada perusahaan tersebut. Penilaian prestasi kerja karyawan secara rutin perlu dilakukan agar diketahui peranan yang aktif dari karyawan dalam mendukung tercapainya tujuan perusahaan. Penilaian prestasi kerja adalah sebuah mekanisme untuk memastikan oprang-orang pada tiap tingkatan mengerjakan tugas-tugas menurut cara-cara yang diinginkan oleh para atasan khususnya para manajer mereka. Dengan melaksanakan penilaian tersebut, para manager dapat berusaha memperbaiki tingkat prestasi bawahan mereka.

\section{Kompensasi Terhadap Motivasi Kerja}

Hasil output SPSS seperti yang tampak pada Tabel 2 yang dilakukan diperoleh angka nilai t hitung variabel $\mathrm{X}_{2}$ lebih besar dari nilai t tabel $(7,211>2,0048)$, dengan tingkat signifikansi sebesar 0,000 , dikarenakan angka taraf signifikansi lebih $<0,05(0,000<0,05)$ maka dapat disimpulkan bahwa kompensasi berpengaruh terhadap motivasi kerja. Berdasarkan dari penjelasan tersebut oleh karena itu $\mathrm{H}_{0}$ ditolak dan $\mathrm{H}_{1}$ diterima, artinya kompensasi secara langsung dan tidak langsung berpengaruh terhadap motivasi kerja karyawan. Hasil penelitian ini sejalan dengan penelitian yang dilakukan oleh (Gunarto et al., 2020), Laminingrum, A.K (2016), dan Haryani, S.S., Hamid, D., dan Susilo, H (2015), dimana hasil penelitiannya kompensasi secara signifikan berpengaruh terhadap motivasi kerja karyawan. Hal ini menjelaskan bahwasanya apabila karyawan memperoleh kompensasi yang sesuai terhadap apa yang telah diberikan oleh karyawan dalam bekerja, maka secara tidak langsung akan meningkatkan motivasi kerja karyawan dalam bekerja. 


\section{Penilaian Prestasi Kerja dan Kompensasi Terhadap Motivasi Kerja Secara Simultan.}

Uji Anova atau $\mathrm{F}$ test diperoleh nilai $\mathrm{F}_{\text {hitung }}$ sebesar 67,352 dengan tingkat probabilitas p-value sebesar 0,000, dikarenakan nilai $\mathrm{F}_{\text {hitung }}>\mathrm{F}_{\text {tabel }}(76,352>3,17)$ sehingga dapat disimpulkan bahwa hipotesis nol $\left(\mathrm{H}_{0}\right)$ ditolak dan Hipotesa alternatif $\left(\mathrm{H}_{1}\right)$ diterima, artinya ada pengaruh signifikan antara penilaian prestasi kerja dan kompensasi secara bersama-sama terhadap motivasi kerja. Dimana besarnya sumbangan penilaian prestasi kerja dan kompensasi mampu menjelaskan variabel motivasi sebesar $71,8 \%$ dan sisanya $28,2 \%$ dipengaruhi oleh variabel lain yang tidak termasuk dalam model ini.

\section{Pengaruh Penilaian Prestasi Kerja dan Kompensasi Secara Langsung dan Tidak Langsung Berpengaruh Terhadap Kinerja. \\ Penilaian Prestasi Kerja Terhadap Kinerja.}

Hasil output SPSS sperti yang tampak pada Tabel 2 yang dilakukan diperoleh angka nilai t hitung variabel $\mathrm{X}_{1}$ lebih besar dari nilai t tabel $(4,084>2,0048)$, dengan tingkat signifikansi sebesar 0,000, dikarenakan angka taraf signifikansi lebih $<0.05(0.000<0.05)$ maka dapat disimpulkan bahwa penilaian prestasi kerja berpengaruh terhadap kinerja karyawan. Berdasarkan dari penjelasan tersebut oleh karena itu $\mathrm{H}_{0}$ ditolak dan $\mathrm{H}_{1}$ diterima, artinya penilaian prestasi kerja secara langsung dan tidak langsung berpengaruh terhadap kinerja karyawan. Hasil ini sejalan dengan penelitian yang dilakukan oleh Sarboini, Adam, M., dan Mahdani (2015), Winarni, R., Muhtadi, A., dan Surahman, E (2016), Yamanie, I.Y., dan Syaharuddin, Y (2016), dan Nuradhawati, R (2017) dimana hasil penelitiannya mengemukakan penilaian prestasi kerja yang dilakukan secara adil dan objektif dapat meningkatkan kinerja karyawan. Penilaian prestasi kerja merupakan salah satu faktor yang mempengeruhi kinerja karyawan, hal ini dikemukakan oleh Hasibuan (2009) yang mengatakan bahwa salah satu kegunaan dari penilaian prestasi kerja adalah untuk meningkatkan motivasi kerja karyawan sehingga dicapai tujuan untuk mendapatkan kinerja yang baik. Penilaian prestasi kerja penting dilaksanakan karena dapat memberikan informasi untuk memperbaiki kinerja perusahaan kedepannya, sebagai dasar kompensasi karyawan, pertimbangan dalam keputusan penempatan jabatan, serta kebutuhan pelatihan, perencanaan, dan pengembangan karir karyawan (Astuti, 2006).

\section{Kompensasi Terhadap Kinerja}

Hasil output SPSS seperti yang tampak pada Tabel 2 yang dilakukan diperoleh angka nilai t hitung variabel $\mathrm{X}_{2}$ lebih besar dari nilai t tabel $(2,538>2,0048)$, dengan tingkat signifikansi sebesar 0,014 , dikarenakan angka taraf signifikansi lebih $<0,05(0,014<0,05)$ maka dapat disimpulkan bahwa kompensasi berpengaruh terhadap kinerja karyawan. Berdasarkan dari penjelasan tersebut oleh karena itu $\mathrm{H}_{0}$ ditolak dan $\mathrm{H}_{1}$ diterima, artinya kompensasi secara langsung dan tidak langsung berpengaruh terhadap kinerja karyawan. Hasil penelitian ini menunjukan hasil yang sama dengan penelitian yang dilakukan oleh (Nguyen et al., 2020), Haryani, S.S., Hamid, D., dan Susilo, H (2015), Winarni, R., Muhtadi, A., dan Surahman, E (2016), Leonardo, E., dan Andreani, F (2015), Riana, N., Fajri, K., dan Alsyaumi, K (2016), Martinus, E., dan Budiyanto (2016) dan Fauzi, S (2014) yang menyatakan bahwa kompensasi memiliki pengaruh yang positif dan signifikan terhadap kinerja. Hal ini menjelaskan bahwasanya jika kompensasi yang diterima oleh karyawan telah sesuai dengan kontribusi yang diberikan oleh karyawan kepada perusahaan, maka dengan senantiasa karyawa akan mampu meningkatkan kinerjanya dengan memberikan kualitas dan kuantitas kerjanya untuk mencapai tujuan perusahaan.

\section{Penilaian Prestasi Kerja dan Kompensasi Terhadap Kinerja Secara Simultan.}

Uji Anova atau $F$ test dengan menggunakan SPSS 21.0 didapat $F_{\text {hitung }}$ sebesar 21,008 dengan tingkat probabilitas $p$-value sebesar 0,000, dikarenakan nilai $F_{\text {hitung }}>F_{\text {tabel }}(21,008>3,17)$ sehingga dapat disimpulkan bahwa hipotesis nol $\left(\mathrm{H}_{0}\right)$ ditolak dan Hipotesa alternatif $\left(\mathrm{H}_{1}\right)$ diterima, artinya ada pengaruh signifikan antara penilaian prestasi kerja dan kompensasi secara bersama-sama terhadap kinerja karyawan. Dimana besarnya peran atau kontribusi variabel penilaian prestasi kerja dan kompensasi mampu menjelaskan variabel kinerja sebesar 44,2\% dan sisanya $55,8 \%$ dipengaruhi oleh variabel lain yang tidak termasuk dalam model ini.

\section{Pengaruh Motivasi Kerja Terhadap Kinerja.}

Hasil output SPSS seperti yang tampak pada Tabel 2 yang dilakukan diperoleh angka nilai thitung variabel $\mathrm{Y}$ lebih besar dari nilai t tabel $(5,352>2,0049)$, dengan tingkat signifikansi sebesar 0,000, dikarenakan angka taraf signifikansi lebih < $0.05(0.000<0.05)$ maka dapat disimpulkan bahwa motivasi berpengaruh terhadap kinerja pegawai. Berdasarkan dari penjelasan tersebut oleh karena itu $\mathrm{H}_{0}$ ditolak dan $\mathrm{H}_{1}$ diterima, artinya motivasi secara langsung berpengaruh terhadap kinerja. Hasil penelitian ini dapat mendukung atau memperkuat teori yang ada, yang menyatakan bahwa apabila dengan memiliki motivasi kerja yang tinggi maka akan menciptakan kegairahan seseorang, agar mau bekerja sama, bekerja efektif dan terintegrasi dengan segala daya upayanya untuk mencapai tujuan 
(Hasibuan, 2009). Selain itu pula hasil penelitian ini juga menunjukan hasil yang sama dengan penelitian yang dilakukan oleh (Nguyen et al., 2020), (Parulian \& Ahmad Hidayat Sutawijaya, 2020), (Anah et al., 2020), Haryani, S.S., Hamid, D., dan Susilo, H (2015) dan Martinus, E., dan Budiyanto (2016) mengungkapkan bahwa motivasi kerja juga akan mampu mempengaruhi dan meningkatkan kinerja. Artinya dengan memiliki motivasi kerja yang tinggi akan mampu memberikan hasil kerja yang maksimal. Motivasi adalah dorongan yang ada dalam diri manusia yang menyebabkan ia melakukan sesuatu (Sopiah, 2015). Dalam kehidupan manusia selalu mengadakan bermacam-macam aktifitas. Salah satu aktivitas itu diwujudkan dalam gerakan-gerakan yang dinamakan kerja.

\section{Pengaruh Penilaian Prestasi Kerja dan Kompensasi Melalui Motivasi Terhadap Kinerja.}

Pengujian hipotesis yang dilakukan diketahui penilaian prestasi kerja dan kompensasi melalui motivasi kerja memiliki pengaruh terhadap kinerja karyawan. Motivasi sebagai proses yang ikut menentukan intensitas, arah, dan ketekunan individu dalam usaha mencapai sasaran. Motivasi sebagai pemberian motif, penimbulan motif atau hal yang menimbulkan dorongan atau keadaan yang menimbulkan dorongan. Setiap individu memerlukan motivasi dalam bekerja. Adanya motivasi akan menimbulkan semangat kerja karena motivasi merupakan suatu dorongan dalam diri seseorang untuk melakukan sesuatu. Dengan kebutuhan yang berbeda-beda maka setiap perilaku individu dalam mencapai tujuan akan berbeda motivasinya (Robbins, 2015).

\section{Simpulan}

Penelitian ini membuat beberapa kesimpulan berdasarkan hasil penelitian dan pembahasan yang sudah dijelaskan pada BAB sebelumnya, yaitu:

a. Penilaian prestasi kerja, kompensasi, motivasi dan kinerja karyawan pada PT. Bank Central Asia. Tbk Kantor Cabang Utama Jambi dalam kondisi yang cukup baik.

b. Penilaian prestasi kerja dan kompensasi secara langsung dan tidak langsung berpengaruh positif dan signifikan terhadap motivasi kerja karyawan pada PT. Bank Central Asia. Tbk Kantor Cabang Utama Jambi.

c. Penilaian prestasi kerja dan kompensasi secara langsung dan tidak langsung berpengaruh positif dan signifikan terhadap kinerja karyawan pada PT. Bank Central Asia. Tbk Kantor Cabang Utama Jambi.

d. Motivasi kerja secara parsial berpengaruh positif dan signifikan terhadap kinerja karyawan pada PT. Bank Central Asia. Tbk Kantor Cabang Utama Jambi.

e. Penilaian prestasi kerja dan kompensasi secara bersama-sama melalui motivasi dapat berpengaruh langsung dan tidak langsung terhadap terhadap kinerja karyawan pada PT. Bank Central Asia. Tbk Kantor Cabang Utama Jambi.

\section{Daftar Pustaka}

Anah, S., Widayati, C. C., \& W., A. (2020). The Effect Of Transformational Leadership Style, Work Motivation And Discipline On Employee Performance. Dinasti International Journal of Digital Business Management. https://doi.org/10.31933/dijdbm.v1i2.159

Astuti, D.A.L.W. (2006). Penciptaan sistem penilaian kinerja yang efektif dengan assessment center. Jurnal Manajemen, Vol. 6, No. 1.

Chandra, O. (2010). Analisis pentingnya penilaian prestasi kerja dalam hubungannya dengan peningkatan motivasi karyawan. Bina Ekonomi Jurnal Unpar, Vol. 5, No. 2.

Fauzi, S. (2014). Pengaruh Kompensasi Terhadap Kinerja Karyawan PT. Trakindo Utama Samarinda. eJournal Ilmu Administrasi Bisnis, Vol. 2, No. 3.

Gunarto, M., Yunilda, \& Yessy Widiastuty. (2020). The Effect Of Compensation And Commitment To Employee Motivation In A Sub-District Palembang. Dinasti International Journal of Management Science. https://doi.org/10.31933/dijms.v1i5.276

Handoko, T. H. (2010). Management personalia dan sumber daya manusia. Yogyakarta: BPFE

Hariandja, M.T.E. (2007). Manajemen sumber daya manusia. Jakarta: Grasindo

Haryani, S.S., Hamid, D., dan Susilo, H. (2015). Pengaruh Kompensasi Terhadap Motivasi Kerja dan Kinerja (Studi Pada Karyawan PT. Telekomunikasi Indonesia, TBK Malang). Jurnal Administrasi Bisnis (JAB), Vol. 25, No.1.

Hasibuan, M.S.P. (2009). Manajemen Sumber Daya Manusia. Jakarta: Bumi Aksara.

Laminingrum, A.K. (2016). Pengaruh Kompensasi Terhadap Motivasi Kerja Pada Karyawan Biro Pelayanan Sosial Dasar Di Sekretariat Daerah Provinsi Jawa Barat. E-Proceeding of Management, Vol. 3, No. 2.

Leonardo, E., dan Andreani, F. (2015). Pengaruh Pemberian Kompensasi Terhadap Kinerja Karyawan Pada PT. Kopanitia. Agora, Vol. 3, No. 2.

Mangkunegara, A.P. (2011). Perencanaan dan Pengembangan Sumber Daya Manusia. Bandung: Refika Aditama. 
Martinus, E., dan Budiyanto. (2016). Pengaruh Kompensasi dan Motivasi Kerja Terhadap Kinerja Karyawan Pada PT. Devina Surabaya. Jurnal Ilmu dan Riset Manajemen, Vol. 5, No. 1.

Nguyen, P. T., Yandi, A., \& Mahaputra, M. R. (2020). Factors That Influence Employee Performance: Motivation, Leadership, Environment, Culture Organization, Work Achievement, Competence And Compensation (A Study Of Human Resource Management Literature Studies). Dinasti International Journal of Digital Business Management.

Nuradhawati, R. (2017). Pengaruh Penilaian Prestasi Kerja dan Pengembangan Karir Terhadap Peningkatan Kinerja Aparatur Daerah Pada Pemerintah Daerah Kabupaten Ciamis. Jurnal Ilmiah Politea FISIP Universitas AlGhifari, Vol. 19, No. 9.

Panggabean, M.S. (2010). Manajemen sumber daya manusia. Bogor: Ghalia Indonesia.

Parulian, S., \& Ahmad Hidayat Sutawijaya. (2020). Effect Of Work Environment And Motivation On Workload And Its Implications On Employee Performance Pt. Pln (Persero) UP3 Kebon Jeruk. Dinasti International Journal of Digital Business Management. https://doi.org/10.31933/dijdbm.v1i2.134

Pribadi, J.A., dan Harjianti, D. (2014). Pengaruh Penilaian Prestasi Kerja Terhadap Motivasi Karyawan Dengan Kompensasi Sebagai Variabel Intervening Pada PT. Enseval Putera Megatrading Cabang Surabaya 2. Agora, Vol. 2, No. 1.

Riana, N., Fajri, K., dan Alsyaumi, K. (2016). Pengaruh Kompensasi Terhadap Kinerja Karyawan Di Kampung Batu Malakasari Tektona Waterpark Kabupaten Bandung. Tourism Scientific Journal, Vol. 2, No. 1.

Rivai, V dan Sagala, E.J. (2011). Manjemen Sumber Daya Manusia Untuk Perusahaan Dari Teori Ke Praktik. Jakarta: RajaGrafindo

Rivai, V. (2009). Manajemen Sumber Daya Manusia untuk Perusahaan: dari Teori ke Praktik. Jakarta: PT Raja Graffindo Persada.

Robbins, S.P \& Judge, T.A. (2015). Perilaku Organisasi. Jakarta: PT. Salemba Empat.

Sarboini, Adam, M., dan Mahdani. (2015). Penilaian Prestasi Kerja dan Promosi Terhadap Motivasi Kerja Serta Dampaknya Pada Kinerja Karyawan Universitas Serambi Mekkah (USM) Aceh. Jurnal Magister Manajemen Pascasarjana Universitas Universitas Syiah Kuala, Vol. 4, No. 2.

Schuler, R.S., Jackson, S.E. (2010). Manajemen sumber daya manusia menghadapi abab ke-21 jilid 2 edisi ke 6. Jakarta: Erlangga.

Sedarmayanti. (2013). Manajemen Sumber Daya Manusia, Reformasi Borokrasi dan Manajemen Pegawai NegeriSipil. Bandung: Refika Aditama.

Simamora, H. (2009). Manajemen Sumber Daya Manusia, edisi keempat, cetakan pertama, Penerbit: YKPN: Yogyakarta

Singarimbun, M \& Effendi, S. (2012). Metode Penelitian Survey. Jakarta: LP3ES.

Soeprihanto, J. (2009). Penilaian Kinerja dan Pengembangan Karyawan. Yogyakarta: BPFE.

Sopiah. (2015). Perilaku Organisasional. Yogyakarta: Andi.

Sutrisno, E. (2014). Manajemen Sumber Daya Manusia. Jakata: Kencana Prenada Media Group.

Wibowo. (2014). Perilaku Dalam Organisasi. Jakarta: RajaGrafindo Persada.

Winarni, R., Muhtadi, A., dan Surahman, E. (2016). Pengaruh Penilaian Prestasi Kerja dan Kompensasi Terhadap Kinerja Tenaga Medis Kefarmasian Non-PNS Instalasi Farmasi RSUP Dr. Hasan Sadikin. Jurnal Farmasi Klinik Indonesia, Vol. 5, No. 4.

Yamanie, I.Y., dan Syaharuddin, Y. (2016). Pengaruh Penilaian Prestasi Kerja, Komitmen Organisasi dan Disiplin Kerja Terhadap Kinerja Karyawan Pada PT. Pelabuhan Indonesia IV Cabang Samarinda. Jurnal Manajemen, Vol. 8, No. 1. 